\title{
Management of Asiatic Citrus Canker Under Field Conditions in Saudi Arabia Using Bacteriophages and Acibenzolar-S-Methyl
}

Yasser E. Ibrahim, Plant Protection Department, College of Food and Agriculture Sciences, King Saud University, Riyadh, Kingdom of Saudi Arabia, and Plant Pathology Research Institute, Agriculture Research Center, Giza, Egypt; Amgad A. Saleh, Plant Protection Department, College of Food and Agriculture Sciences, King Saud University, Riyadh, Kingdom of Saudi Arabia, and Agricultural Genetic Engineering Research Institute, Agriculture Research Center, Giza, Egypt; and Mohammed A. Al-Saleh, Plant Protection Department, College of Food and Agriculture Sciences, King Saud University, Riyadh, Kingdom of Saudi Arabia

\begin{abstract}
Applications of formulated bacteriophages with skim milk and sucrose or nonformulated bacteriophages combined with acibenzolar-S-methyl (ASM) were compared with copper bactericides applications for suppressing Asiatic citrus canker (ACC) caused by Xanthomonas citri subsp. citri $(X c c)$ on leaves under greenhouse and field conditions in Saudi Arabia. Bacteriophages were applied one day prior to inoculation of Mexican lime (Citrus aurantifolia) plants with Xcc, then twice a week until the end of the trials. Copper hydroxide was applied once prior to inoculation and then every seven days afterward, whereas ASM was applied one week prior to inoculation and then every 21 days afterward. Under greenhouse conditions,

the incidence of ACC on leaves was reduced significantly from 75.2 to $12.8 \%$ or $18.3 \%$ for plants treated with copper hydroxide or bacteriophages in combination with ASM, respectively. Applications of formulated phages in combination with ASM as soil drench under field conditions significantly decreased disease incidence by $14.8 \%$ (Trial 1) and 16.8\% (Trial 2) compared with untreated control plants. Overall, the $X c c$-inoculated plants treated with bacteriophages + ASM combination showed significant ACC reduction under greenhouse and field conditions. The bacteriophages + ASM combination tested in these trials can be an effective tool in the integrated management programs of Asiatic citrus canker disease.
\end{abstract}

Asiatic citrus canker (ACC) caused by Xanthomonas citri subsp. citri $(X c c)$ is a major threat to citrus production not only in Saudi Arabia but in all humid, subtropical production zones (Gottwald et al. 2002; Ibrahim and Bayaa 1989). ACC was probably introduced to the Arabian Peninsula, including Saudi Arabia and United Arab Emirates, in the early 1980s (Civerolo, 1988). It has spread rapidly since its discovery. Although many attempts have been made to eradicate the disease, it is now considered to be endemic in three of the eleven main citrus-growing regions in Saudi Arabia (Al Saleh et al. 2014; Ibrahim and Bayaa 1989). Citrus canker is a serious problem for Saudi Arabian growers due to the frequent rainfall and warm temperatures during most of the citrus vegetative period. The establishment of Xcc populations in groves can result in major indirect losses like the ban of fresh fruit export and, directly, through fruit losses.

Copper-based bactericides are routinely applied to control ACC in the three endemic Saudi citrus-growing regions. However, the extensive use of copper compounds can lead to soil contamination that has direct harmful effects on both humans and surrounding ecosystems (Alva 1993). In addition, excessive exposure to copper can select $X c c$ strains that are copper resistant (Canteros et al. 2008). Copper-resistant Xcc strains have not yet been isolated from Saudi Arabia, but they could appear with continued reliance upon copper bactericides for ACC management. In recent years, alternative management strategies to reduce ACC were investigated with some degree of success (Balogh et al. 2010). Antibiotic-based products are one of these alternative solutions, however they have not shown to be as effective as copper for controlling ACC because of their limited residual activity on foliar surfaces, even when applied at two-week intervals (Graham et al. 2006). Nevertheless, the application of copper is not effective for protecting young, susceptible

Corresponding author: Yasser E. Ibrahim; E-mail: yasereid@ksu.edu.sa

The authors would like to extend their sincere appreciation to the Deanship of Scientific Research, King Saud University, Saudi Arabia, for its funding of this research group no. RG-1438-065.

Accepted for publication 22 December 2016.

(c) 2017 The American Phytopathological Society citrus foliage against $X c c$ infection, due to the rapid expansion of young leaves and the limited mobility of copper after its application.

The use of systemic acquired resistance (SAR) inducers has shown activity against a number of bacterial plant diseases (Vallad and Goodman 2004), but they have not been effective in controlling ACC when applied alone (Graham and Leite 2004). When the SAR-inducers acibenzolar-Smethyl (ASM) and harpin protein were used in combination with copper oxychloride or with copper hydroxide, they did not effectively reduce ACC incidence on foliage under field conditions compared with copper alone (Graham and Leite 2004).

Bacteriophages, another promising alternative strategy for controlling ACC, have been used to control many bacterial phytopathogenic agents (Balogh et al. 2003; Civerolo and Keil 1969; Frampton et al. 2014; Lang et al. 2007; Obradovic et al. 2004, 2005; Tanaka et al. 1990). Balogh et al. (2008) reported that phage treatment reduced ACC in nursery settings but less so than a copper-mancozeb bactericide. However, combining bacteriophages with SAR inducers has been used effectively in reducing the disease severity of tomato bacterial spot and onion leaf blight (Lang et al. 2007; Obradovic et al. 2004). Phage treatments also showed effective results when they were used in combination with other biocontrol agents against pathogenic bacteria causing fire blight on pear and tobacco bacterial wilt (Schnabel et al. 1999; Tanaka et al. 1990). Combining bacteriophages with SAR inducers may be an effective management strategy for Xcc but no study has been reported using this combination to manage ACC. Therefore, the objectives of this study were to better understand bacteriophage ecology of the citrus phyllosphere under Saudi Arabian conditions and to develop an alternative management program for ACC using a combination of bacteriophage and ASM under greenhouse and field conditions.

\section{Materials and Methods}

Inoculum production. A copper-sensitive strain of Xcc $\mathrm{A}^{*}$ (JQ890095) preserved in $50 \%$ glycerol at $-80^{\circ} \mathrm{C}$ was plated on nutrient agar, incubated overnight at $28^{\circ} \mathrm{C}$, and then transferred to nutrient broth (Merck Millipore, Germany) on a rotary shaker at $28^{\circ} \mathrm{C}$ for $24 \mathrm{~h}$. Bacteria were harvested by centrifugation and resuspended in sterilized distilled water. The bacterial concentration was photometrically adjusted to $1 \times 10^{6}$ colony forming units $(\mathrm{CFU}) / \mathrm{ml}$. Concentrations of $X c c$ viable cells were confirmed by dilution plating on nutrient agar plates. Bacteriophages were isolated from Mexican lime 
leaves with characteristic canker lesions. The leaf tissue samples were placed in $125-\mathrm{ml}$ flasks containing $50 \mathrm{ml}$ sterilized distilled water and shaken for $20 \mathrm{~min}$. To remove debris, 2- $\mathrm{ml}$ aliquots were collected and centrifuged at $10,000 \mathrm{~g}$ for $10 \mathrm{~min}$. The supernatants were passed through a $0.45-\mu \mathrm{m}$ membrane filter and resulting filtrates were stored in microfuge tubes in complete darkness at $4^{\circ} \mathrm{C}$. Isolated bacteriophages were mixed with $X c c$ and then the mixture was spread on plates containing soft nutrient agar medium ( $10 \mathrm{~g} / \mathrm{liter}$ ). If lysis was observed after $24 \mathrm{~h}$ incubation at $28^{\circ} \mathrm{C}$, the phage was purified by three subsequent single-plaque isolations steps. Six morphologically distinct plaques were selected and mixed to infect $X c c$ bacteria grown in either semisolid nutrient agar-yeast extract medium (NYA) $(0.8 \%$ NB, $0.6 \%$ Bacto agar [Difco], and $0.2 \%$ Yeast Extract [Difco]) or liquid nutrient broth. The propagated bacteriophage mixture was stored in SM (sodium chloride/magnesium sulfate) buffer $(0.05 \mathrm{M}$ Tris- $\mathrm{HCl}, \mathrm{pH} 7.5$, $0.1 \mathrm{M} \mathrm{NaCl}, 10 \mathrm{mM} \mathrm{MgSO}_{4}$, and $1 \%$ gelatin) at $4{ }^{\circ} \mathrm{C}$ in complete darkness. Either SM buffer or sterilized distilled water was used for preparing phage suspension. Serial dilutions were used to determine phage concentrations after 24 to $48 \mathrm{~h}$. The phage concentration was calculated from the plaque number and specific dilution was expressed as plaque forming units (PFU)/ml (Rizvi and Mora 1963).

Greenhouse trials. Two-year-old Mexican lime (C. aurantifolia) plants growing in 2.5-liter containers of a general-purpose peat-based soil were maintained in a greenhouse at King Saud University (KSU), Plant Protection Department, Riyadh, Saudi Arabia. Day/night temperatures were $28 / 22 \pm 2{ }^{\circ} \mathrm{C}$. Four weeks before applying different treatments, the Mexican lime plants were trimmed to approximately $40 \mathrm{~cm}$, allowing only one shoot per plant to grow to approximately 20 to $30 \mathrm{~cm}$ in order to obtain four to five $75 \%$ expanded immature leaves suitable for $X c c$-inoculation. Bacteria $\left(1 \times 10^{6} \mathrm{CFU} / \mathrm{ml}\right)$ were misted onto the plant foliage with a hand-held sprayer to near runoff. The ASM (Actigard 50WG, Syngenta Crop Protection, Greensboro, NC) was applied as either a foliar spray at $1 \mathrm{mM}(150 \mathrm{ml}$ of solution per plant sprayed to near runoff) 4 days prior to $X c c$-inoculation or a soil drench at $4.1 \mathrm{mM}$ per plant 7 days prior to inoculation. The phage mixture was used at $5 \times 10^{9} \mathrm{PFU} / \mathrm{ml}$. The phage solution was applied as a foliar spray $24 \mathrm{~h}$ before inoculation in the evening. Copper hydroxide $\left(\mathrm{Cu}(\mathrm{OH})_{2}\right.$, Kocide 2000, 35\% metallic $\mathrm{Cu}$ ) was applied at $1.3 \mathrm{~g} /$ liter as a foliar spray $24 \mathrm{~h}$ before inoculation and then applied weekly. The greenhouse treatments were: ASM as a soil drench, nonformulated bacteriophage, ASM as a foliar spray, ASM combined with nonformulated bacteriophage, and copper hydroxide. Plants treated with sterilized distilled water were used as mock inoculation controls (Table 1). To maintain high relative humidity, the treated plants were covered with white plastic bags. After $24 \mathrm{~h}$, the treated plants were removed from the bags, allowed to dry, inoculated with $X c c$, and then covered again with the bags. After $24 \mathrm{~h}$, plants were removed from the bags and placed on the greenhouse bench. Disease was assessed 4 weeks after the last application. Disease incidence was calculated as the percentage of diseased leaves with canker symptoms per plant. Disease intensity was determined by calculating the average number of lesions divided by the total number of lesions.

Field trials. Approximately three-year-old Mexican lime trees (a height of 40 to $50 \mathrm{~cm}$ with 25 to 30 leaves per plant) grown in containers were selected with the basal leaves of the new flush approximately three-quarter expanded. The trees were grown in a greenhouse until being transported to a field site at the research station of King Saud University. Based on the results of greenhouse trials, the following compounds were selected for testing ACC under field conditions: ASM (used as a soil drench at $4.1 \mathrm{mM}$ per plant), nonformulated bacteriophage (suspended in sterilized distilled water), and a formulated bacteriophage (suspended in $7.5 \mathrm{~g} /$ liter skim milk and $2.5 \mathrm{~g} / \mathrm{liter}$ sucrose) (Iriarte et al. 2007). The ASM, bacteriophage, and their combinations were evaluated in spray programs along with copper hydroxide. The phage was applied twice a week, whereas the copper was applied once a week. The ASM was applied four times at a time interval of 21 days (Table 1). Three blocks were used. Each block had 5 plants per treatment. Plants were spaced $50 \mathrm{~cm}$ apart within each block. The plants were inoculated with $X c c \mathrm{~A}^{*}$ strain, as previously described, using a hand-held sprayer in October of 2014 and 2015. Disease incidence and intensity were determined as previously described in greenhouse trials. Monthly counts of citrus canker incidence on leaves were used to calculate the area under disease progress curve (AUDPC) according to the method of Shaner and Finney (1977).

Experimental design. Experimental design for greenhouse experiments was arranged in a completely randomized design with 15 plants per treatment. The experiment was repeated once. Field trials were designed as randomized complete block design with three blocks, each block had four treatments. Each treatment had five trees. The experiment was conducted twice for reproducibility.

Statistical analysis. Data collected from the two greenhouse trials were pooled when no significant differences were found according to Bartlett's test $(P>0.05)$ (Statistix 8, 2003; Analytical Software, Tallahassee, FL). Canker infected leaves (\%) and disease intensity were subjected to a one-way ANOVA using SAS PROC GLM (SAS version 9.1, SAS Institute Inc., Cary, NC). Significant differences among

Table 1. Different treatments applied to Mexican lime plants to evaluate their effectiveness in controlling Asiatic citrus canker under greenhouse and open-field conditions in Saudi Arabia

\begin{tabular}{|c|c|c|c|}
\hline Treatments & No. of applications $s^{x}$ & Concentration ${ }^{y}$ & Application timing ${ }^{\mathrm{Z}}$ \\
\hline \multicolumn{4}{|l|}{ Greenhouse trial } \\
\hline \multicolumn{4}{|l|}{ Drench treatments } \\
\hline Water & - & - & - \\
\hline Actigard & 4 & $4.1 \mathrm{mM}$ per tree & $7 / 21$ \\
\hline \multicolumn{4}{|l|}{ Foliar treatments } \\
\hline Phage $^{\mathrm{v}}$ & Biweekly & $5 \times 10^{9} \mathrm{PFU}$ & $1 / 15$ \\
\hline Actigard & 4 & $1 \mathrm{mM}$ & $4 / 21$ \\
\hline Actigard + Phage & $4+$ biweekly & $1 \mathrm{mM}+5 \times 10^{9} \mathrm{PFU}$ & \\
\hline Copper hydroxide & Weekly & $1.3 \mathrm{~g} / \mathrm{liter}$ & $1 / 7$ \\
\hline Untreated control & - & - & - \\
\hline \multicolumn{4}{|l|}{ Field trial } \\
\hline Untreated control & - & & \\
\hline Actigard $^{\mathrm{w}}+$ nonformulated phage & Biweekly & $5 \times 10^{9} \mathrm{PFU}$ & $1 / 15$ \\
\hline Actigard + formulated phage & 4 & $1 \mathrm{mM}$ & $4 / 21$ \\
\hline Copper hydroxide & Weekly & $1.3 \mathrm{~g} / \mathrm{liter}$ & $1 / 7$ \\
\hline
\end{tabular}


treatment means were determined using Fisher's least significant difference (LSD) at $P<0.05$.

For field trials, canker-infected leaves (\%), the area under the disease progress curve (AUDPC, calculated from six readings of citrus canker incidence on leaves), and disease intensity data were subjected to a two-way ANOVA using SAS PROC GLM. Blocks were treated as a random effect. Due to the detection of a significant year-treatment interaction, a one-way ANOVA was performed for each year. Treatment means were separated using Fisher's LSD at $P<0.05$.

\section{Results}

Greenhouse trials. All treatments significantly $(P<0.0001)$ reduced the incidence of canker on leaves compared with the untreated Xcc-inoculated control (UTC) (Table 2). Either phage application alone or ASM significantly reduced ACC incidence on leaves; however, they provided less control than copper alone in the two trials (Table 2). Interestingly, the combination of phage and ASM treatments significantly $(P<0.0001)$ reduced citrus canker disease development and was as effective as the copper hydroxide treatment alone. Combination of phage/ASM had a disease incidence on leaves as low as

Table 2. Effect of soil drench or foliar spray applications of Actigard, nonformulated phage, and their combination on both percentage of canker-infected leaves and the severity of citrus canker lesions of Mexican lime plants inoculated with $X c c$ at $1 \times 10^{6} \mathrm{CFU} / \mathrm{ml}$ in the greenhouse

\begin{tabular}{lcc}
\hline Treatments $^{\mathbf{w}}$ & ${\text { Canker-infected leaves }(\%)^{\mathbf{x}}}$ & Disease intensity $^{\mathbf{Z}}$ \\
\hline Soil drench & $74.3 \mathrm{a}^{\mathrm{y}}$ & \\
Water & $38.2 \mathrm{bc}$ & $3.8 \mathrm{a}$ \\
Actigard & & $3 \mathrm{bc}$ \\
Foliar spray & $30.4 \mathrm{c}$ & \\
Phage & $48.1 \mathrm{~b}$ & $2.8 \mathrm{c}$ \\
Actigard & $18.3 \mathrm{~d}$ & $3.3 \mathrm{~b}$ \\
Actigard + Phage & $12.8 \mathrm{~d}$ & $2.2 \mathrm{~d}$ \\
Copper hydroxide & $75.2 \mathrm{a}$ & $2 \mathrm{~d}$ \\
Untreated control & $<0.0001$ & $4 \mathrm{a}$ \\
$P$ value & $<0.0001$ \\
\hline
\end{tabular}

${ }^{\mathrm{w}}$ Actigard was applied at $4.1 \mathrm{mM}$ per tree per application for drench treatment and $1 \mathrm{mM}$ (150 ml of solution per plant sprayed to near runoff) for spray treatment. Phage mixtures $\left(5 \times 10^{9}\right.$ plaque forming units $[\mathrm{PFU}] / \mathrm{ml}$ were applied either in sterilized distilled water or with a suspension of $0.75 \%$ skim milk powder and $2.5 \mathrm{~g} /$ liter sucrose. Copper hydroxide was applied at 1.3 $\mathrm{g} /$ liter $\left(\mathrm{Cu}(\mathrm{OH})_{2}\right.$, Kocide $2000,35 \%$ metallic $\left.\mathrm{Cu}\right)$.

${ }^{x}$ Disease incidence was calculated as the percentage of diseased leaves with canker symptoms per plant in each plot.

y Treatments within a column followed by the same letter are not significantly different based on Fischer's protected least significance difference.

${ }^{z}$ Disease intensity was determined by collecting all diseased leaves from a plot (the total number of lesions and calculating the average lesion number per diseased leaf).
$18.3 \%$ compared with $75.2 \%$ of the untreated control. There was not a significant difference in ACC incidence on leaves between ASMsoil drench (38.2\%) and ASM-foliar spray (48.1\%); however, the former tended to reduce disease more than the later (Table 2).

Effect of phage and ASM applications on ACC disease development under field conditions. The effect of nonformulated and formulated phage in combination with ASM was evaluated for reducing ACC under field conditions. Generally, there were significant differences $(P<0.0001)$ among treatments in canker incidence and disease intensity (Table 3). Overall, the UTC plants showed the highest disease incidence. The combination of formulated phage and ASM treatment significantly reduced citrus canker incidence and was as effective as the copper hydroxide treatment alone (Table 3). When phage was applied with skim milk in combination with ASM, the ACC development was significantly reduced. However, the application of phage without skim milk resulted in a higher disease incidence and disease development compared with either copper alone or formulated phage combined with ASM (Table 3). For example, the combination of nonformulated phage with ASM showed 42.4 to $56.9 \%$ reduction in ACC incidence, compared with 82.1 to $86.1 \%$ reduction in ACC incidence due to the application of formulated phage combined with ASM. Moreover, after two days post-application, no phages could be recovered from the plants treated with nonformulated phage; however, the phage recovery from plants treated with formulated phage ranged from $10^{5}$ to $10^{7} \mathrm{PFU} / \mathrm{ml}$. According to the area under the disease-progress curve (AUDPC), no statistically significant difference was observed between the combination of phage + ASM and copper (Table 3).

\section{Discussion}

The main objective of this study was to assess the efficacy of an environmentally friendly management program for ACC using ASM, phage, and their combination under greenhouse and field conditions. In the two greenhouse trials, ASM suppressed ACC on leaves when applied alone with four sprays at $1 \mathrm{mM}$ concentrations. Although the defense mechanisms induced by ASM could not completely prevent ACC, plants treated with ASM alone had significantly less disease than the UTC. Llorens et al. (2015) reported that $1 \mathrm{mM}$ concentration of ASM significantly reduced ACC symptoms on sweet orange for up to 45 days after application. However, Graham and Leite (2004) showed that six applications of foliar ASM with or without copper formulations per season did not provide additional control of ACC on sweet orange leaves and fruits compared with copper alone under field conditions. Multiple foliar applications of ASM, particularly under biotic and abiotic stresses, have a phytotoxic impact on plant developmental, physiological, and biochemical activities (Chinnasri et al. 2006; Chung et al. 2013; Francis et al. 2009; Louws et al. 2001). To avoid ASM phytotoxicity, its application rate and frequency must be optimized (Graham and Myers 2011). The reduced number of ASM

Table 3. Effect of Actigard as a soil drench in combination with formulated and nonformulated phages compared with copper hydroxide on percentage of cankerinfected leaves, the severity of citrus canker lesions and the area under disease progress curve (AUDPC) on Mexican lime plants inoculated with Xcc at $1 \times 10^{6}$ $\mathrm{CFU} / \mathrm{ml}$ under field conditions

\begin{tabular}{|c|c|c|c|c|c|c|}
\hline Disease parameters & Treatment & $\begin{array}{c}\text { Untreated } \\
\text { control }\end{array}$ & $\begin{array}{c}\text { Actigard + nonformulated } \\
\text { Phage }^{\mathrm{y}}\end{array}$ & Actigard + formulated Phage & $\mathrm{Cu}(\mathrm{OH})_{2}{ }^{\mathrm{z}}$ & $P$ value \\
\hline \multirow[t]{2}{*}{$\overline{\text { Canker-infected leaves }(\%)^{\mathrm{u}}}$} & Trial 1 & $70.2 \mathrm{a}^{\mathrm{x}}$ & $30.2 \mathrm{~b}$ & $12.5 \mathrm{c}$ & $8.3 \mathrm{~d}$ & $P<0.0001$ \\
\hline & Trial 2 & $66.6 \mathrm{a}$ & $38.3 \mathrm{~b}$ & $9.2 \mathrm{c}$ & $7.8 \mathrm{c}$ & $P<0.0001$ \\
\hline \multirow[t]{2}{*}{ Disease intensity ${ }^{\mathrm{v}}$} & Trial 1 & $2.4 \mathrm{a}$ & $2.0 \mathrm{~b}$ & $1.8 \mathrm{c}$ & $1.8 \mathrm{c}$ & $P<0.0001$ \\
\hline & Trial 2 & $2.8 \mathrm{a}$ & $2.1 \mathrm{~b}$ & $1.9 \mathrm{bc}$ & $1.7 \mathrm{c}$ & $P<0.0005$ \\
\hline \multirow{2}{*}{ AUDPC $^{\mathrm{w}}$} & Trial 1 & $34.2 \mathrm{a}$ & $22.2 \mathrm{~b}$ & $14.8 \mathrm{~d}$ & $17.6 \mathrm{c}$ & $P<0.0001$ \\
\hline & Trial 2 & $31.2 \mathrm{a}$ & $24.1 \mathrm{~b}$ & $16.8 \mathrm{c}$ & $16.4 \mathrm{c}$ & $P<0.0005$ \\
\hline
\end{tabular}

u Disease incidence was calculated as the percentage of diseased leaves with canker symptoms per plant in each plot.

$\checkmark$ Disease intensity was determined by collecting all diseased leaves from a plot and then the total number of lesions on the collected diseased leaves were divided by the total number of collected diseased leaves to get the average lesion number per diseased leaf.

w AUDPC was calculated according to Shaner and Finney (1977).

x Means within the same row followed by the same letter are not significantly different based on Fischer's protected least significance difference.

y Actigard was applied at $4.1 \mathrm{mM}$ per tree per application for drench treatment and $1 \mathrm{mM}(150 \mathrm{ml}$ of solution per plant sprayed to near runoff) for spray treatment. Phage mixtures $\left(5 \times 10^{9}\right.$ plaque forming units $\left.(\mathrm{PFU}) / \mathrm{ml}\right)$ were applied either in sterilized distilled water or with a suspension of $0.75 \%$ skim milk powder and $2.5 \mathrm{~g} /$ liter sucrose.

${ }^{\mathrm{z}} \mathrm{CH}$ : Copper hydroxide was applied at $1.3 \mathrm{~g} /$ liter $\left(\mathrm{Cu}(\mathrm{OH})_{2}\right.$, Kocide $2000,35 \%$ metallic $\left.\mathrm{Cu}\right)$. 
sprays (four sprays) under greenhouse and field conditions led to increased ACC suppression on Mexican lime leaves. This reduction in disease may be due to the lower stress on plants and better overall plant health. In tomato plants receiving ASM alone at weekly intervals for the entire season, only the first six applications showed significant bacterial spot reduction compared with the untreated plants (Roberts et al. 2008). In the present study, no significant difference was observed in ACC incidence on leaves between soil-drench and foliar-spray ASM treatments; however, the former tended to reduce disease more than the latter. ASM applied as a drench effectively reduced Xcc canker lesions up to $70 \%$ on seedlings of the 'Swingle' citrumelo hybrid (Citrus paradisi $\times$ Poncirus trifoliata) compared with those that were untreated but inoculated (Francis et al. 2009). The longevity of activity produced by ASM when used as a soil drench is similar to the insecticide imidacloprid in its gradual release in soil, uptake by the roots, and then progressive translocation to actively growing shoots (Sur and Stork 2003). The ability of ASM to elicit plant defense responses against many phytopathogenic agents increases its potential role in integrated disease management programs for many diseases (Graham and Leite 2004; Obradovic et al. 2004; 2005).

The foliar application of bacteriophages for disease management has been reported in several pathosystems (Jones et al. 2012). In this study, a nonformulated mixture of six phages collected from Saudi Arabian citrus orchards was primarily tested for control of ACC under greenhouse conditions. Nonformulated phage applied under greenhouse conditions provided a significant reduction in ACC incidence on leaves compared with the UTC in the two greenhouse trials. This result is in agreement with Balogh et al. (2008), where nonformulated phage treatments significantly reduced disease severity of ACC. Moreover, twice-weekly spray applications of a nonformulated mixture of four phages specific to $X$. campestris pv. vesicatoria, the causal agent of tomato bacterial spot, reduced significantly disease severity on plants compared with copper-mancozeb applications (Flaherty et al. 2000). Obradovic et al. (2005) similarly showed that nonformulated phages provided significant disease reduction of tomato bacterial spot under greenhouse conditions. In addition, bacteriophages collected from apple and pear orchards reduced fire blight infection on apple flowers of potted apple trees (Boulé et al. 2011).

Although formulations are intended to mainly protect and increase phage longevity, they may also have the unintended consequence of creating a conducive environment for disease development. Balogh et al. (2008) found that the application of phage with skim milk increased disease severity of ACC under greenhouse conditions. There are many reasons that may explain their unexpected finding. Among them, skim milk may serve as a carbon and nitrogen source for the bacteria and promote ACC development. In addition, it was proposed that some formulation components, e.g., skim milk, might facilitate the pathogen entrance through breakdown of surface tension. In contrast, under field conditions, environmental parameters may affect formulation compounds to work against Xcc (Crisp et al. 2006).

Based on results from the greenhouse experiments, we focused on application of ASM in combination with bacteriophage under field conditions. In contrast to the application of nonformulated phages in greenhouse experiments, different formulations (protectors) have been proposed to extend the residual activity of bacteriophages under field conditions to protect them from environmental factors, such as rain and sunlight-UV, that negatively affect the survival of bacteriophages (Balogh et al. 2003; Jones et al. 2007). It was reported that the persistence of phage on the leaf surface was improved when skim milk was added to phage suspension (Balogh et al. 2003; Iriarte et al. 2007). According to the two consecutive field trials, the formulated phage in combination with ASM resulted in 82.1 to $86.1 \%$ reduction in ACC incidence compared with 42.4 to $56.9 \%$ reduction for nonformulated phage in combination with ASM. Combining formulated bacteriophages with SAR inducers provided significant disease reduction in many bacterial plant diseases such as tomato bacterial spot and Xanthomonas leaf blight of onion (Lang et al. 2007; Obradovic et al. 2004).

Overall, the ASM/formulated phage combination offered an additional reduction in disease, representing an effective, alternative strategy to applications of ASM, phage, or copper alone. The application of bacteriophages on leaf surfaces may result in a reduction in bacterial populations along with the induction of plant defense reactions by ASM, and collectively provide significant disease reduction. Based on the field experiments, the combination of ASM and phage may be an effective new strategy for citrus growers to manage ACC and could also be employed for reducing the rate and frequency of copperbactericide applications for highly susceptible young trees.

Before large-scale application, further studies are needed to verify the efficacy of combining ASM with phage in effectively controlling ACC under wider range of Saudi Arabian field conditions. Moreover, it is important to measure the dynamics of naturally occurring $X c c$ populations to determine the ratio of phage to $X c c$ for adequate control. A genetically diverse population of Xcc should be used during the process of determining phage lyse ability. Because phage population tends not to be effective from one year to the next (Jones et al. 2012), it is also recommended to reisolate it seasonally to obtain newly-evolved virulent ones. In addition, mutant phages can be used to minimize the occurrence of phage-resistant Xcc strains.

\section{Literature Cited}

Al-Saleh, M. A., Widyawan, A., Saleh, A., and Ibrahim, Y. E. 2014. Distribution and pathotype identification of Xanthomonas citri subsp. citri recovered from southwestern region of Saudi Arabia. Afr. J. Microbiol. Res. 8:673-679.

Alva, A. K. 1993. Copper contamination of sandy soils and effects on young Hamlin orange trees. Bull. Environ. Contam. Toxicol. 51:857-864.

Balogh, B., Canteros, B. I., Stall, R. E., and Jones, J. B. 2008. Control of citrus canker and citrus bacterial spot with bacteriophages. Plant Dis. 92:10481052 .

Balogh, B., Jones, J. B., Iriarte, F. B., and Momol, M. T. 2010. Phage therapy for plant disease control. Curr. Pharm. Biotechnol. 11:48-57.

Balogh, B., Jones, J. B., Momol, M. T., Olson, S. M., Obradovic, A., King, P., and Jackson, L. E. 2003. Improved efficacy of newly formulated bacteriophages for management of bacterial spot on tomato. Plant Dis. 87:949-954.

Boulé, J., Sholberg, P. L., Lehman, S. M., O'Gorman, D. T., and Svircev, A. M. 2011. Isolation and characterization of eight bacteriophages infecting Erwinia amylovora and their potential as biological control agents in British Columbia, Canada. Can. J. Plant Pathol. 33:308-317.

Canteros, B. I., Rybak, M., Gochez, A., Velazquez, P., Rivadeneira, M., Mitidieri, M., Garran, S., and Zequeira, L. 2008. Occurrence of copper resistance in Xanthomonas axonopodis pv. citri in Argentina. Phytopathology 98:S30.

Chinnasri, B., Sipes, B. S., and Schmitt, D. P. 2006. Effects of Inducers of Systemic Acquired Resistance on Reproduction of Meloidogyne javanica and Rotylenchulus reniformis in Pineapple. J. Nematol. 38:319-325.

Chung, W. H., Deepak, S. A., and Ishii, H. J. 2013. Effect of acibenzolar-S-methyl, strobilurins and other fungicide treatments on phylloplane fungi of crops. J. Gen. Plant Pathol. 79:128-135.

Civerolo, E. L. 1988. Preliminary assessment of citrus bacterial canker and greening diseases in Saudi Arabia. Food and Agric. Org. of the UN, Rome, Italy.

Civerolo, E. L., and Keil, H. L. 1969. Inhibition of bacterial spot of peach foliage by Xanthomonas pruni bacteriophage. Phytopathology 12:1966-1967.

Crisp, P., Wicks, T. J., Troup, G., and Scott, E. S. 2006. Mode of action of milk and whey in the control of grapevine powdery mildew. Australas. Plant Pathol. 35:487-493.

Flaherty, J. E., Jones, J. B., Harbaugh, B. K., Somodi, G. C., and Jackson, L. E. 2000. Control of bacterial spot on tomato in the greenhouse and field with H-mutant bacteriophages. HortScience 35:882-884.

Frampton, R. A., Taylor, C., Holguín Moreno, A. V., Visnovsky, S. B., Petty, N. K., Pitman, A. R., et al. 2014. Identification of bacteriophages for biocontrol of the kiwifruit canker phytopathogen Pseudomonas syringae pv. actinidiae. Appl. Environ. Microbiol. 80:2216-2228.

Francis, M. I., Redondo, A., Burns, J. K., and Graham, J. H. 2009. Soil application of imidacloprid and related SAR inducing compounds produces effective and persistent control of citrus canker. Eur. J. Plant Pathol. 124:283-292.

Gottwald, T. R., Graham, J. H., and Schubert, T. S. 2002. Citrus canker: The pathogen and its impact. Plant Management Network http://www.plantmanagementnetwork. org/pub/php/review/citruscanker/

Graham, J. H., Gottwald, T. R., and Leite, R. P. 2006. Prospects for control of citrus canker with novel chemical compounds. Proc. Fla. State Hortic. Soc. 119:82-88.

Graham, J. H., and Leite, R. P. 2004. Lack of control of citrus canker by induced systemic resistance compounds. Plant Dis. 88:745-750.

Graham, J. H., and Myers, M. E. 2011. Soil application of SAR inducers imidacloprid, thiamethoxam, and acibenzolar-S-methyl for citrus canker control in young grapefruit trees. Plant Dis. 95:725-728.

Ibrahim, G., and Bayaa, B. 1989. Fungal, bacterial and nematological problems of citrus, grape and stone fruits in Arab countries. Arab J. Plant Prot. 7:190-197.

Iriarte, F. B., Balogh, B., Momol, M. T., Smith, L. M., Wilson, M., and Jones, J. B. 2007. Factors affecting survival of bacteriophage on tomato leaf surfaces. Appl. Environ. Microbiol. 73:1704-1711. 
Jones, B., Jackson, L. E., Balogh, B., Obradovic, A., Iriarte, F. B., and Momol, M. T. 2007. Bacteriophages for Plant Disease Control. Annu. Rev. Phytopathol. 45: 245-262.

Jones, J. B., Vallad, G. E., Iriarte, F. B., Obradović, A., Wernsing, M. H., Jackson, L. E., Balogh, B., Hong, J. C., and Momol, M. T. 2012. Considerations for using bacteriophages for plant disease control. Bacteriophage 2:208-214.

Lang, J. M., Gent, D. H., and Schwartz, H. F. 2007. Management of xanthomonas leaf blight of onion with bacteriophages and a plant activator. Plant Dis. 91: 871-878.

Llorens, E., Vicedo, B., Lopez, M. M., Lapena, L., Graham, J. H., and García-Agustín, P. 2015. Induced resistance in sweet orange against Xanthomonas citri subsp. citri by hexanoic acid. Crop Prot. 74:77-84.

Louws, F. J., Wilson, M., Cuppels, D. A., Jones, J. B., Shoemaker, P. B., Sahin, F., and Miller, S. A. 2001. Field control of bacterial spot of tomato and pepper and bacterial speck of tomato using a plant activator. Plant Dis. 85:481-488.

Obradovic, A., Jones, J. B., Momol, M. T., Balogh, B., and Olson, S. M. 2004. Management of tomato bacterial spot in the field by foliar applications of bacteriophages and SAR inducers. Plant Dis. 88:736-740.

Obradovic, A., Jones, J. B., Momol, M. T., Olson, S. M., Jackson, L. E., Balogh, B., Guven, K., and Iriarte, F. B. 2005. Integration of biological control agents and systemic acquired resistance inducers against bacterial spot on tomato. Plant Dis. 89:712-716.

Rizvi, S., and Mora, P. T. 1963. Bacteriophage plaque-count assay and confluent lysis on plates without bottom agar layer. Nature 200:1324-1325.

Roberts, P. D., Momol, M. T., Ritchie, L., Olson, S. M., Jones, J. B., and Balogh, B. 2008. Evaluation of spray programs containing famoxadone plus cymoxanil, acibenzolar-S-methyl, and Bacillus subtilis compared to copper sprays for management of bacterial spot on tomato. Crop Prot. 27:1519-1526.

Schnabel, E. L., Fernando, W. G. D., Meyer, M. P., Jones, A. L., and Jackson, L. E. 1999. Bacteriophage of Erwinia amylovora and their potential for biocontrol. Acta Hortic.: 649-54.

Shaner, G., and Finney, R. E. 1977. The effect of nitrogen fertilization on the expression of slow-mildewing resistance in Knox wheat. Phytopathology 67:1051-1056.

Sur, R., and Stork, A. 2003. Uptake, translocation and metabolism of imidacloprid in plants. Bull. Insectology 56:35-40.

Tanaka, H., Negishi, H., and Maeda, H. 1990. Control of tobacco bacterial wilt by an avirulent strain of Pseudomonas solanacearunm M4S and its bacteriophage. Ann. Phytopathol. Soc. Jpn. 56:243-46.

Vallad, G. E., and Goodman, R. M. 2004. Systemic acquired resistance and induced systemic resistance in conventional agriculture. Crop Sci. 44:1920-1934. 